\title{
Effect of Chemical Contraception on Serum Testosterone in Dogs
}

\author{
Aeknath Virendra ${ }^{1 *}$, Om Prakash Shrivastava ${ }^{1}$, Satya Nidhi Shukla ${ }^{1}$, \\ Manish Kumar Shukla ${ }^{2}$, Nitin Bajaj ${ }^{1}$, Aditya Mishra ${ }^{3}$, Rajesh Vandre ${ }^{4}$, \\ Ranbir Singh Jatav ${ }^{5}$ and Shashi Pradhan ${ }^{5}$
}

${ }^{1}$ Department of Animal Reproduction, Gynaecology and Obstetrics, ${ }^{3}$ Department of Veterinary Physiology, ${ }^{4}$ Department of Animal Genetics and Breeding, ${ }^{5}$ Department of

Veterinary Medicine, Nanaji, Deshmukh Veterinary Science University, Jabalpur, M.P. 482001, India

${ }^{2}$ Department of Animal Reproduction, Gynaecology and Obstetrics, Sardar Vallabhbhai Patel University, Meerut, U.P. 250110, India

*Corresponding author

\begin{tabular}{|c|c|}
\hline & A B S T R A C T \\
\hline Keywords & \multirow{8}{*}{$\begin{array}{l}\text { Various methods of sterilization in dogs such as relocation, deterrence, surgical } \\
\text { interventions etc. are used to control stray dog population. Chemical sterilization } \\
\text { is gaining popularity nowadays over other methods because of its economics, easy } \\
\text { to perform and least complications. Thus, the present study was designed to } \\
\text { explore the contraceptive effect of intra-testicular injection of zinc gluconate } \\
\text { neutralized with arginine and chlorhexidine gluconate in twenty-four sexually } \\
\text { mature male mongrel dogs by measuring the difference in blood testosterone level } \\
\text { in male dogs. Three experimental groups (each group having six dogs) viz Group } \\
\text { I, Group II and Group III were treated zinc gluconate neutralized with arginine, } \\
5 \% \text { chlorhexidine gluconate and } 4 \% \text { chlorhexidine gluconate, respectively and } \\
\text { group IV having six dogs were kept as control. Blood testosterone level via } \\
\text { ELISA were measured at day } 0,7,15 \text { and } 30 \text {. Blood testosterone level of all } \\
\text { experimental groups was not significantly changed. }\end{array}$} \\
\hline Canıne & \\
\hline & \\
\hline $\begin{array}{l}\text { Chlorhexidine } \\
\text { gluconate, }\end{array}$ & \\
\hline & \\
\hline A & \\
\hline & \\
\hline & \\
\hline
\end{tabular}

\section{Introduction}

Canine overpopulation and stray dogs represent a worldwide problem, compromising public health and animal welfare. This problem has a negative influence on environmental hygiene and zoonoses. This is of particular importance in the developing countries, where implementation of population control strategies may conflict with local cultural perspectives. The canine population control is a necessary preventive public health action that has to be constantly performed at the municipality level as a complementary measure for canine zoonoses control, specifically with respect to rabies (13).

Contraception serves to reduce the size of animal population. Furthermore, it is carried out because of medical indications as well as behavioral problems. The most frequently 
mentioned undesirable male behaviors are aggression towards other animals or people, roaming, fighting with other males, inappropriate sexual behavior (mounting of other animals or people) $(5,6)$.

Nowadays in large scale sterilization campaigns for controlling dog population the chemical sterilization is gaining more popularity as an alternative to surgical sterilization. An ideal non-surgical sterilizing agent would be one which arrests androgenesis and spermatogenesis (12), besides safety, efficacy, economy, permanent and predictable effects on behavior and health. The chemical contraception is based on bilateral intra-testicular injections of chemical preparations, ultimately leading to pathological changes in the gonads and infertility or sterility. This method of sterilization is simple and inexpensive in comparison to surgical procedure and can be used in areas with large numbers of stray animals (4). Different chemical compounds, such as saline solutions, formalin, zinc gluconate, chlorhexidine gluconate and calcium chloride are being investigated.

An intratesticular injection containing $0.2 \mathrm{M}$ zinc gluconate neutralized to $\mathrm{pH} 7.0$ with 0.2 $\mathrm{M}$ arginine (13.1 $\mathrm{mg} \mathrm{zinc} / \mathrm{ml})$, has been used for sterilizing male dogs. This type of sterilization is based on bilateral intratesticular injections of chemical compound, resulting into pathological changes in the gonads and infertility. A predetermined amount of zinc solution is injected into each testis of puppies of 3 to 10 months of age ultimately leading to induction of almost complete fibrosis of the seminiferous tubules and Leydig cells within two to three months post injection $(1,3,9)$.

Keeping in view the above preliminary finding suggesting the permanent sterilizing effect of zinc gluconate and chlorhexidine in male dogs, the present study was designed with the objective, to study the effect of zinc gluconate and chlorhexidine gluconate on blood testosterone concentration in male dogs.

\section{Materials and Methods}

\section{Animals experimentation}

The present study was conducted in twentyfour apparently healthy mongrel stray male dogs with intact and developed testicles. All the dogs were free of any anatomic or reproductive disorders. All the dogs were housed individually in separate kennels at TVCC, College of Veterinary Science and AH, Jabalpur, M.P., India and were fed a balanced diet along with the ad-libitum clean drinking water. Animal experimentation was in alignment with Ethical Committee of aforesaid college.

The dogs were randomized into four groups of six dogs each as G-I, G-II, G-III and G-IV (control) and the study was designed as mentioned in table 1 .

\section{Intratesticular injection}

All the animals were sedated using atropine sulphate $(0.025 \mathrm{mg} / \mathrm{kg}$ b. wt. Kaptrop, Iskon Remedies) and xylazine (1mg/kg b.wt. Xylaxin, Indian Immunologicals Limited) for the administration of intratesticular injection. The animals were off-feed 6-12 hrs before the injection of atropine and xylazine. Once sedated the dogs were restrained in supine position and the testicular region was cleaned using antiseptic solution (10\% Povidone iodine solution Unidine, Unichem laboratories limited).

In G-I animals $2 \mathrm{ml}$ of zinc gluconate neutralized with arginine was injected into each testicle, in G-II and G-III $2 \mathrm{ml}$ of $5 \%$ 
chlorhexidine gluconate and $4 \%$ chlorhexidine gluconate respectively was injected into each testicle using a 26 gauge needle with sterile syringe with a $0.45 \times 13 \mathrm{~mm}$ of needle, into the center of the testicle via dorso-cranial portion of testicle, parallel to the longitudinal axis and the G-IV animals were kept as control and no treatment was given to them (A larger gauge needle should not be used because it may lead to the leakage of the drug and the handling of the testes should be held firmly).

\section{Serum testosterone estimation}

Approximately 3-5 $\mathrm{ml}$ of blood sample was collected from saphenous vein of each dog of all the groups into vacuum tubes with clot activator on day 0 before treatment and on day 7,15 and 30 after the intratesticular injection. The tubes were then centrifuged at $3000 \mathrm{rpm}$ for 10 minutes. The serum samples were isolated in eppendroff tubes of $0.5 \mathrm{ml}$ and stored at $-20^{\circ} \mathrm{C}$ in deep freeze until the hormone analysis.

Testosterone concentration in serum samples was measured using a commercial ELISA kit (Testosterone ELISA kit; Cat. No.: SG-
10770; Sinogeneclon biotech Co., Ltd, Hangzhou, China). The detection range and the sensitivity of the assay was $0.1 \mathrm{ng} / \mathrm{ml}$ to $20 \mathrm{ng} / \mathrm{ml}$ and $0.05 \mathrm{ng} / \mathrm{ml}$ respectively.

\section{Statistical analysis}

The quantitative data were analyzed by oneway ANOVA for testosterone concentration to compare the mean value between the days and within the different groups using SPSS 24 software. Results were described as the mean \pm S.E (8).

\section{Results and Discussion}

The blood samples were collected on day 0,7 , 15 and 30 and serum was isolated and assayed for the testosterone concentration using ELISA technique.

Statistical analysis was done with the help of IBM SPSS-24 software, using one-way ANOVA with descriptive statistics $(P \leq 0.05)$ and Duncan post hoc multiple range test. No significant difference was recorded in serum testosterone among the four groups (Table 2 and Fig. 1).

Table.1 Treatment schedule for chemical castration in male dogs

\begin{tabular}{|c|c|l|l|c|}
\hline Group & $\begin{array}{c}\text { Animals } \\
\text { (n) }\end{array}$ & \multicolumn{1}{|c|}{ Treatment } & \multicolumn{1}{|c|}{ Dose } & Parameter \\
\hline I & 6 & $\begin{array}{l}\text { Intra-testicular } \\
\text { injection of zinc } \\
\text { gluconate neutralized } \\
\text { with arginine }\end{array}$ & $\begin{array}{l}\text { 2ml }(10 \mathrm{mg} / \mathrm{ml}) \text { of } \\
\text { zinc gluconate } \\
\text { neutralized with } \\
\text { arginine }\end{array}$ & $\begin{array}{l}\text { Blood testosterone } \\
\text { concentration on day } \\
0,7,15 \& 30 .\end{array}$ \\
\hline II & 6 & $\begin{array}{l}\text { Intratesticular injection } \\
\text { of chlorhexidine } \\
\text { gluconate }\end{array}$ & $\begin{array}{l}\text { 2ml of } 5 \% \\
\text { chlorhexidine } \\
\text { gluconate }\end{array}$ & \\
\hline III & 6 & $\begin{array}{l}\text { Intratesticular injection } \\
\text { of chlorhexidine } \\
\text { gluconate }\end{array}$ & $\begin{array}{l}\text { 2ml of } \\
\text { chlorhexidine } \\
\text { gluconate }\end{array}$ & \\
\hline IV & 6 & $\begin{array}{l}\text { No treatment } \\
\text { Healthy dogs will } \\
\text { be kept as control }\end{array}$ & \\
\hline
\end{tabular}


Table.2 Mean testosterone concentration $(\mathrm{ng} / \mathrm{ml})$ before and after treatment in dogs

\begin{tabular}{|c|c|c|c|c|}
\hline \multirow{2}{*}{ Group } & \multicolumn{4}{|c|}{ Mean testosterone concentration (ng/ml) } \\
\cline { 2 - 5 } & Day 0 & Day 7 & Day 15 & Day 30 \\
\hline Group I & $5.21 \pm 0.18$ & $5.22 \pm 0.90$ & $5.87 \pm 0.92$ & $3.88 \pm 0.58$ \\
\hline Group II & $4.77 \pm 0.66$ & $6.24 \pm 0.81$ & $4.96 \pm 0.40$ & $4.62 \pm 0.64$ \\
\hline Group III & $5.84 \pm 0.67$ & $4.65 \pm 0.29$ & $4.02 \pm 0.72$ & $4.53 \pm 0.61$ \\
\hline Group IV & $5.25 \pm 0.21$ & $5.45 \pm 0.28$ & $5.34 \pm 0.38$ & $5.51 \pm 0.32$ \\
\hline
\end{tabular}

Fig.1 Administration of intratesticular chemical

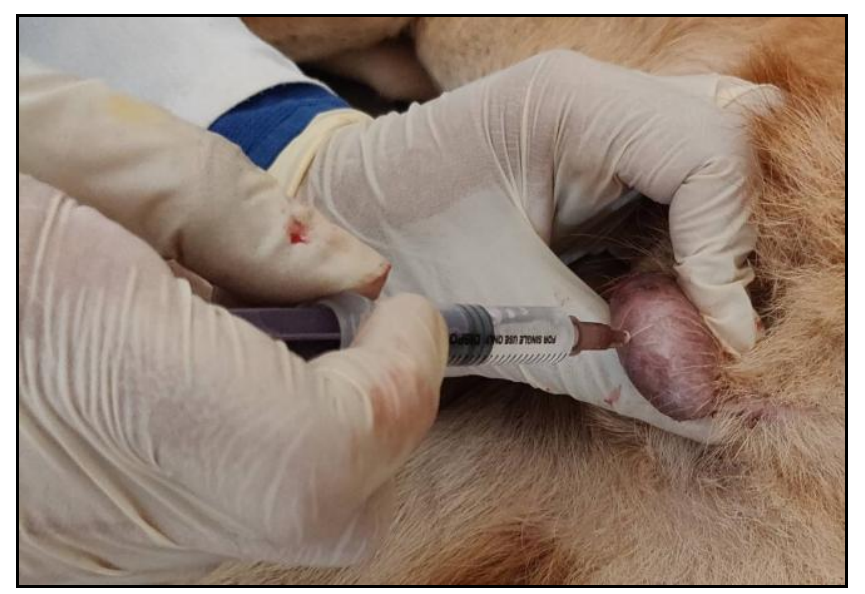

The global dog population is estimated to be around 700 million (3). Overpopulation of stray and feral dogs is an universal problem and raises public health concerns related to the increased risk of zoonotic diseases and compromise of the environmental health that may foster the permanence of diseases in other species or the degradation of ecosystems (1) as well as to the social and urban problems associated with animalhuman conflicts.

To overcome the burning problem of canine overpopulation contraception may be the possible solution which in turn can be achieved by confinement or surgical or chemical methods. Various chemical methods are now in vogue, and it is not always realized, even by veterinary surgeons, that the way these chemicals work is not fully understood, and that for this reason alone they are inherently dangerous. All methods are associated with some danger but whereas in the case of confinement or surgery the dangers are most likely to be immediate, adverse results from the use of chemical contraceptives may not appear for many years.

In present study, diminution in testosterone level was also observed on day 30 in comparison to day 0 in treatment groups. However, the difference was statistically nonsignificant, which may be attributed to sterility by blocking sperm transport from the testes to the epididymides without affecting testosterone production. A non-significant decrease in the testosterone levels was also recorded in treated groups with zinc gluconate $(2,7,10)$ in consonance with the present study. The seminiferous tubules of testes and lumen contained sperm while epididymis contained no sperm indicating inhibition of sperm transport from the testes to the 
epididymides which may be the reason for the non- significant difference in the testosterone concentration (2). However, 41-52\% reduction in testosterone level in zinc gluconate injected dog in comparison to control dogs has also been documented (12). Vannucchi et al. (2015) concluded that injection of Zinc gluconate effectively reduces testosterone levels achieving sterility while maintaining normal body function (11). Hence, an additional study is further suggested by involving a large animal number and for longer observation period in order to replace surgical castration with chemical castration.

In conclusion the non-significant diminutive changes in serum testosterone level were observed 30 days post administration of intratesticular injection of zinc gluconate neutralized with arginine, 5\% Chlorhexidine gluconate and $4 \%$ chlorhexidine gluconate.

\section{Acknowledgment}

We are very thankful to Nanaji Deshmukh veterinary science university, Jabalpur, Madhya Pradesh for providing basic facilities for this research.

\section{References}

1. Brown, G., 2003. Advances in reproductive control technology. In: Association AV, (ed.). $13^{\text {th }}$ National Urban Animal Management Conference, Caloundra, Queensland.: 107-9.

2. Fahim, M. S., Wang, M., Sutcu, M. F., Fahim, Z. and Yougquist, R. S. 1993. Sterilization of dogs with intraepididymal injection of zinc arginine. Contraception, 47: 107-122.

3.Hughes, J. and Macdonald, D. W. 2013. A review of the interactions between free-roaming domestic dogs and wildlife. Biological Conservation, 157:
341-51.

4. Kutzler, M. and Wood, A. 2007. Nonsurgical methods of contraception and sterilization. Theriogenology, 66: 51425.

5. Maarschalkerweerd, R. J., Endenburg, N., Kirpensteijn, J. and Knol, B. W. 1997. Influence of orchiectomy on canine behaviour. Vet. Rec., 140: 617-619.

6. Neilson, J. C., Eckstein, R. A. and Hart, B. L. 1997. Effects of castration on problem behaviours in male dogs with reference to age and duration of behavior. Journal of the American Veterinary Medical Association, 211: 180-184.

7. Oliveira, E. C., Moura, M. R., de Sa, M. J., Silva Jr., V. A., Kastelic, J. P., Douglas, R. H. and Marques, Junior, A. P. 2012. Permanent contraception of dogs induced with intratesticular injection of a Zinc Gluconate-based solution. Theriogenology, 77: 10561063.

8. Snedecor, G. W. and Cochran, W. G. 1994. Statistical Methods, $8^{\text {th }}$ Edn., Oxford and IBH Publishing Co: 291-293.

9. Tepsumethanon, V., Wilde, H. and Hemachudha, T. 2005. Intratesticular injection of a balanced zinc solution for permanent sterilization of dogs. J.l of Med. Asso. Thialand, 88: 686-689.

10. Vanderstichel, R., Forzan, N., Perez, G., Serpell, J. and Garde, E. 2015. Changes in Blood Testosterone Concentrations after Surgical and Chemical Sterilization of Male FreeRoaming Dogs in Southern Chile. Theriogenology,83: 1021- 1027.

11. Vannucchi, C. I., Angrimani, D. S. R., Eyherabide, A. R., Mazzei, C. P., Lucio, C. F. and Maiorka, P. C. 2015. Effects of intratesticular administration of zinc gluconate and dimethyl sulfoxide on clinical, endocrinological and reproductive parameters in dogs. 
Theriogenology, 84: 1103-1110.

12. Wiebe, J. P. and Barr, K. J. 1984. The control of male fertility by 1,2,3trihydroxypropane (THP; glycerol) rapid arrest of spermatogenesis without altering libido, accessory organs, gonadal steroidogenesis, and serum testosterone, $\mathrm{LH}$ and FSH. Contraception, 29: 291-302.

13. W. H. O. 1992. Expert committee on rabies. $8^{\text {th }}$ Report. Geneva, pp. 87.

\section{How to cite this article:}

Aeknath Virendra, Om Prakash Shrivastava, Satya Nidhi Shukla, Manish Kumar Shukla, Nitin Bajaj, Aditya Mishra, Rajesh Vandre, Ranbir Singh Jatav and Shashi Pradhan. 2020. Effect of Chemical Contraception on Serum Testosterone in Dogs. Int.J.Curr.Microbiol.App.Sci. 9(08): 2938-2943. doi: https://doi.org/10.20546/ijcmas.2020.908.329 